\title{
RESEARCH
}

\section{Thyroxine promotes lung cancer growth in an orthotopic mouse model}

\author{
S Latteyer'1, S Christoph2, S Theurer ${ }^{3}$, G S Hönes'1, K W Schmid³, D Führer ${ }^{1}$ and L C Moeller ${ }^{1}$ \\ 'Department of Endocrinology, Diabetes and Metabolism, University of Duisburg-Essen, Essen, Germany \\ ${ }^{2}$ Clinic for Bone Marrow Transplants, University of Duisburg-Essen, Essen, Germany \\ ${ }_{3}^{3}$ Institute of Pathology, University of Duisburg-Essen, Essen, Germany
}

Correspondence should be addressed to L C Moeller: lars.moeller@uni-due.de

\begin{abstract}
Thyroid hormones are important for physiology and homeostasis. In addition to nuclear thyroid hormone receptors, the plasma membrane protein integrin $\alpha_{v} \beta_{3}$ has been recognized as a receptor for both thyroxine $\left(T_{4}\right)$ and triiodothyronine $\left(T_{3}\right)$. Here, we studied whether thyroid hormone promotes growth of murine lung cancer via $\alpha_{v} \beta_{3}$ in vivo. Murine Lewis lung carcinoma cells (3LL), stably transfected with luciferase, were injected into mouse lungs. Tumor growth in untreated mice was compared to hypothyroid mice and hypothyroid mice treated with $T_{3}$ or $T_{4}$ with or without the $\alpha_{v} \beta_{3}$ inhibitor 3,5,3',5'-tetraiodothyroacetic acid (Tetrac). Tumor progression was determined by serial in vivo imaging of bioluminescence emitted from the tumor. Tumor weight was recorded at the end of the experiment. Neoangiogenesis was determined by immunohistochemistry for CD31. Tumor growth was reduced in hypothyroidism and increased by $T_{4}$ treatment. Strikingly, only $T_{4}$ but not $T_{3}$ treatment promoted tumor growth. This $\mathrm{T}_{4}$ effect was abrogated by the $\alpha_{v} \beta_{3}$ inhibitor Tetrac. Tumor weight and neoangiogenesis were also significantly increased only in $\mathrm{T}_{4}$-treated mice. The $\mathrm{T}_{4}$ effect on tumor weight and neoangiogenesis was abolished by Tetrac. In vitro, T4 did not stimulate $3 \mathrm{LL}$ cell proliferation or signaling pathway activation. We conclude that $\mathrm{T}_{4}$ promotes lung cancer growth in this orthotopic mouse model. The tumor-promoting effect is mediated via the plasma membrane integrin $\alpha_{v} \beta_{3}$ and increased neoangiogenesis rather than direct stimulation of $3 \mathrm{LL}$ cells. These data suggest that such effects of levothyroxine may need to be considered in cancer patients on $\mathrm{T}_{4}$ substitution.
\end{abstract}

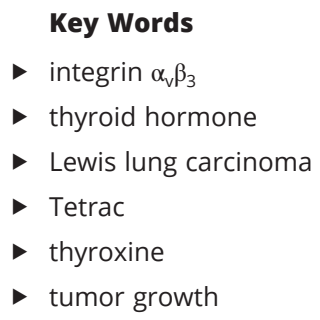

\section{Introduction}

The thyroid hormones (THs) thyroxine $\left(\mathrm{T}_{4}\right)$ and triiodothyronine $\left(\mathrm{T}_{3}\right)$ are mostly recognized for their roles in normal growth, development and metabolism. These effects are typically mediated by $\mathrm{T}_{3}$ and the intracellular thyroid hormone receptors (TRs) $\alpha$ and $\beta$. THs are transported into target cells. There, $\mathrm{T}_{3}$ activates the canonical pathway by binding to TRs, which act as a transcription factors and promote the expression of target genes (type 1 TH signaling) (Flamant et al. 2017). Another mechanism of $\mathrm{T}_{3}$ action is rapid activation of the PI3K pathway via TRs (TR-dependent signaling of TH without DNA binding, type 3 TH signaling) (Cao et al. 2009, Flamant et al. 2017, Hönes et al. 2017).

In addition to these intracellular $\mathrm{TH}$ actions, $\mathrm{T}_{3}$ and $\mathrm{T}_{4}$ bind to the plasma membrane protein integrin $\alpha_{v} \beta_{3}$, which mediates the signal across the membrane
(C) 2019 Society for Endocrinology Published by Bioscientifica Ltd. Printed in Great Britain 
(TR-independent $\mathrm{TH}$ signaling, type $4 \mathrm{TH}$ signaling) (Bergh et al. 2005, Flamant et al. 2017). $\alpha_{v} \beta_{3}$ is expressed on malignant cells and in inflammatory sites, especially in activated macrophages, monocytes, neutrophils, natural killer cells, naive T lymphocytes and endothelial cells (Piali et al. 1995, Eliceiri \& Cheresh 1998, Wilder 2002, Niu et al. 2007). This integrin $\alpha_{\mathrm{v}} \beta_{3}$ contains two TH binding sites, S1 and S2, which activate different downstream pathways (Davis et al. 2011, Freindorf et al. 2012): $S 1$ binds $T_{3}$ and activates the PI3K/AKT pathway, whereas $\mathrm{S} 2$ binds $\mathrm{T}_{4}$ and, with lower affinity, $\mathrm{T}_{3}$ and activates PI3K/AKT pathway and MAPK pathway (Lin et al. 2009). TH action at $\alpha_{v} \beta_{3}$ is inhibited by the deaminated and decarboxylated $\mathrm{T}_{4}$ derivative Tetrac (3,3,5', $5^{\prime}$-tetraiodothyroacetic acid) (Bergh et al. 2005). Thus, THs influence cells via several distinct pathways initiated by intracellular and membrane receptors.

Besides their role in development and physiology, THs also play a role in pathological conditions. THs can directly stimulate cancer cell proliferation in vitro, for example, lung adenocarcinoma (Kinoshita et al. 1991), breast carcinoma (Hall et al. 2008) and prostate cancer cells (Tsui et al. 2008). These TH effects are thought to be mediated by integrin $\alpha_{v} \beta_{3}$ and not the canonical TRs $\alpha$ and $\beta$, because the stimulatory effect can be inhibited by pretreatment with Tetrac (Lin et al. 2008, 2009, Meng et al. 2011). Furthermore, Tetrac suppressed the expression of EGFR, VEGF, multiple cyclins, catenins and cytokines in human tumor cells (Davis et al. 2014).

As thyroxine is one of the most widely prescribed drugs and cancer is the second leading cause of death, a considerable number of cancer patients will be on thyroxine substitution. It is therefore important to study the effects of $\mathrm{T}_{3}$ and $\mathrm{T}_{4}$ on cancer progress in vivo. Here, we demonstrate in an orthotopic mouse model that $\mathrm{T}_{4}$ promotes growth of murine non-small-cell lung cancer (NSCLC) cells.

\section{Materials and methods}

\section{Cell culture}

Lewis lung carcinoma cells (3LL) were kindly provided by Raphael Nemenoff (University of Colorado, Denver, CO, USA) and stably transfected with pCCL-MNDU3-LUC plasmid containing the firefly luciferase gene as previously described (Supplementary Fig. 1, see section on supplementary data given at the end of this article) (Christoph et al. 2013). The cell line was validated before start of the experiments by short tandem repeats
(Microsynth Seqlab, Göttingen, Germany). Cells were cultured in RPMI 1640 medium (Hyclone Laboratories, Logan, UT, USA) supplemented with $10 \%$ fetal bovine serum in $5 \% \mathrm{CO}_{2}$ at $37^{\circ} \mathrm{C}$ to $65-70 \%$ confluence. For the proliferation assay, cells were grown in RPMI 1640 medium with $10 \%$ fetal bovine serum (FBS) depleted of TH by treatment of FCS with anion exchange resin (Aldrich Amberlite IRA-400 Cl, Sigma) and charcoal. Thyroid hormone concentration was below the limit of detection after treatment. $\mathrm{T}_{4}, \mathrm{~T}_{3}$ and Tetrac were dissolved in DMSO, which was also used as control.

\section{Proliferation assay}

To study the influence of $\mathrm{T}_{4}$ on growth of $3 \mathrm{LL}$ cells in vitro, $10^{5}$ cells were seeded on day one in triplicates in TH-depleted FBS. 3LL cells were cultured in the absence of $\mathrm{T}_{4}$ or supplemented with $100 \mathrm{nM}, 1 \mu \mathrm{M}, 10 \mu \mathrm{M}$ and $100 \mu \mathrm{M}$ T4. Medium was renewed every $2-3$ days. On day 3,5 and 8 all 3LL cells were harvested and counted in a Neubauer chamber. The experiment was repeated three times.

\section{Western blot}

$0.4 \times 10^{6}$ 3LL cells were seeded in a six-well plate. Twentyfour hours later, medium was changed to RPMI 1640 medium supplemented with 2.5\% TH-depleted FBS for 16 hours. The following day cells were stimulated with different concentration of $\mathrm{T}_{4}$ or Tetrac (dissolved in $0.01 \mathrm{M}$ $\mathrm{NaOH}$ and $0.1 \% \mathrm{BSA}$ ) for $30 \mathrm{~min}$ as previously described (Bergh et al. 2005). As an internal positive control, 3LL cells were also stimulated with $50 \mathrm{ng} / \mathrm{mL}$ EGF (Sigma Aldrich) for $5 \mathrm{~min}$. After the stimulation, whole-protein lysates were obtained using RIPA buffer $(150 \mathrm{mM} \mathrm{NaCl}$, $50 \mathrm{mM} \mathrm{HCl}, 1 \%$ Nonidet P-40, $0.5 \%$ sodium deoxycholate, $0.1 \%$ SDS, $2 \mathrm{mM}$ EDTA, $50 \mathrm{mM} \mathrm{NaF}$ ) supplemented with complete protease and PhosSTOP inhibitor (Roche). Thirty micrograms of protein were separated on a $10 \%$ SDS-polyacrylamide gel, transferred onto PVDF membrane overnight at $4^{\circ} \mathrm{C}$. PVDF membranes were blocked with $5 \%$ milk powder for $1 \mathrm{~h}$. The following primary antibodies were used: pAKT (S473) (Cell Signaling, No. 4060), pERK1/2 (T202,Y204) (Cell Signaling, No.4370) and $\alpha$-Tubulin (Merck Millipore, 05-829).

\section{Gene expression analysis}

Total RNA was isolated from 3LL cells (RNeasy Kit, Qiagen) and stored at $-80{ }^{\circ} \mathrm{C}$. Two micrograms of total RNA were reverse transcribed into cDNA with 
SuperScript III (Invitrogen) and random hexamer primers. qRTPCR was performed using Roche SYBR Green I Master Mix on a LightCycler LC480 (Roche). Primer sequences will be provided at request. Expression was normalized on that of 18 S RNA. Ct values $<35$ were used for analysis and calculation of the fold change in gene expression by the efficiency-corrected method (Pfaffl 2001).

\section{Animals and treatments}

B6(Cg)-Tyr-2J (C57BL/6J) were obtained from The Jackson Laboratory. All animal studies were approved by the Landesamt für Natur, Umwelt und Verbraucherschutz Nordrhein-Westfalen (LANUV, Germany) and were performed according to the German Regulations for Laboratory Animal Science (GVSOLAS) and the European Health Law of the Federation of Laboratory Animal Science Associations (FELASA). Animals were housed under standard laboratory conditions (temperature $22 \pm 1^{\circ} \mathrm{C}$ and $12 \mathrm{~h}$ light, $12 \mathrm{~h}$ dark light cycle. Food and water were provided ad libitum. At the age of 7 weeks, male mice were randomized into treatment groups $(n=6$ per group). The euthyroid group received control diet (Harlan Laboratories, Roßdorf, Germany) and tap water. In all other groups, hypothyroidism was induced 21 days prior to injection of 3LL cells by feeding low iodine diet (Harlan Laboratories, Roßdorf, Germany) and 0.02\% methimazole (Sigma Aldrich), 0.5\% sodium perchlorate monohydrate (Sigma Aldrich) and 0.3\% saccharin (Sigma Aldrich) in the drinking water. Hypothyroidism condition was maintained until the end of experiment.

Overall, 500,000 luciferase-tagged 3LL cells were resuspended in $40 \mu \mathrm{L}$ HBSS containing 10\% Matrigel (Matrix Growth Factor Reduced, BD Biosciences, San Jose, CA, USA) for orthotopic injection (Poczobutt et al. 2013). Cell viability was determined by trypan blue dye staining, and cells were used if viability was $>95 \%$. Mice were deeply anesthetized with isoflurane inhalation. Local anesthesia was administered subcutaneously with $50 \mu \mathrm{L} 0.5 \%$ lidocaine $(2.5 \mathrm{mg} / \mathrm{kg})$. The right chest wall was disinfected and a small skin incision $(\sim 3 \mathrm{~mm})$ was made along the right lateral axillary line at the level of the xiphoidal process. Cells were directly injected into the lung parenchyma of mice and the wound was closed with a liquid topical tissue adhesive surgibond (SMI AG Steinerberg, St. Virth, Belgium).

Starting 7 days after surgery, treatment group animals received intraperitoneal injections of $T_{4}$ $1 \mu \mathrm{g} / \mathrm{g}$ body weight, $\mathrm{T}_{3} 45 \mathrm{ng} / \mathrm{g}$ body weight and/or
Tetrac $1 \mu \mathrm{g} / \mathrm{g}$ body weight (Supplementary Fig. 2). $\mathrm{T}_{3}$ and $\mathrm{T}_{4}$ were injected i.p. 5 times/week and Tetrac i.p. 3 times/week. All reagents were purchased from Sigma Aldrich and dissolved in $0.01 \mathrm{M} \mathrm{NaOH}, 0.1 \%$ BSA and diluted in phosphate buffered saline (PBS) 1:10. Solutions were prepared freshly every week and were kept protected from light at $4^{\circ} \mathrm{C}$. Control groups received $0.01 \mathrm{M} \mathrm{NaOH}$ and 0.1\% BSA diluted in PBS 1:10 i.p. Mice were euthanized when predefined criteria according to GVSOLAS were reached, for example, gasping or severe body weight loss. After mice were euthanized, blood was collected from heart, incubated on ice for $30 \mathrm{~min}$ and centrifuged for $20 \mathrm{~min}$ with $17,000 \boldsymbol{g}$ at $4^{\circ} \mathrm{C}$. Serum was collected and stored at $-80^{\circ} \mathrm{C}$ until measurement. Before tissue collection, mice were perfused with heparinized saline through a needle placed in the right ventricle. Tumor tissue was removed, weighed and used for either flow cytometry or immunohistochemistry.

\section{In vivo bioluminescence imaging}

Mice were anesthetized with 1.5-2\% isofluorane during imaging procedures. Bioluminescence was detected with an IVIS Lumina II imaging system (Perkin Elmer) 5 min after intraperitoneal injection of $150 \mu \mathrm{g} / \mathrm{g}$ D-luciferin (Perkin Elmer) dissolved in PBS. Mice were imaged with sequential 30, 60, 90 and 120s of exposure. Changes in bioluminescence intensity over time were measured and are presented as total flux values in photons per second. The total flux was calculated in regions of interest (ROI) on each mouse with Living Image 4.1 acquisition and analysis software (Perkin Elmer).

\section{Flow cytometry}

Lung tumor tissue was digested with collagenase type IV (150 U/ml, Worthington Biochemical, Lakewood, NJ, USA) and DNase $\left(10 \mathrm{U} / \mathrm{ml}\right.$, Sigma Aldrich) for $1 \mathrm{~h}$ at $37^{\circ} \mathrm{C}$ and minced through cell strainers to dissociate cells. Single cell suspensions of $1 \times 10^{6}$ cells were incubated with anti-CD16/32 antibody for $10 \mathrm{~min}$, washed and then incubated $20 \mathrm{~min}$ for extracellular receptors (anti-CD3, anti-CD4, anti-CD8, anti-CD11, anti-CD51, anti-CD61, anti-NK1.1, anti-Ly-6G/Ly-6C and anti-F4/80). After the incubation, cells were fixed and flow cytometry was performed on a BD FACS Aria III (BD Biosciences). For intranuclear staining of Foxp3 (Biolegend, San Diego, CA, USA) samples where additionally incubated for $30 \mathrm{~min}$. Data were analyzed with FlowJo V10 (FlowJo, Ashland, OR, USA). (c) 2019 Society for Endocrinology Published by Bioscientifica Ltd. Printed in Great Britain 

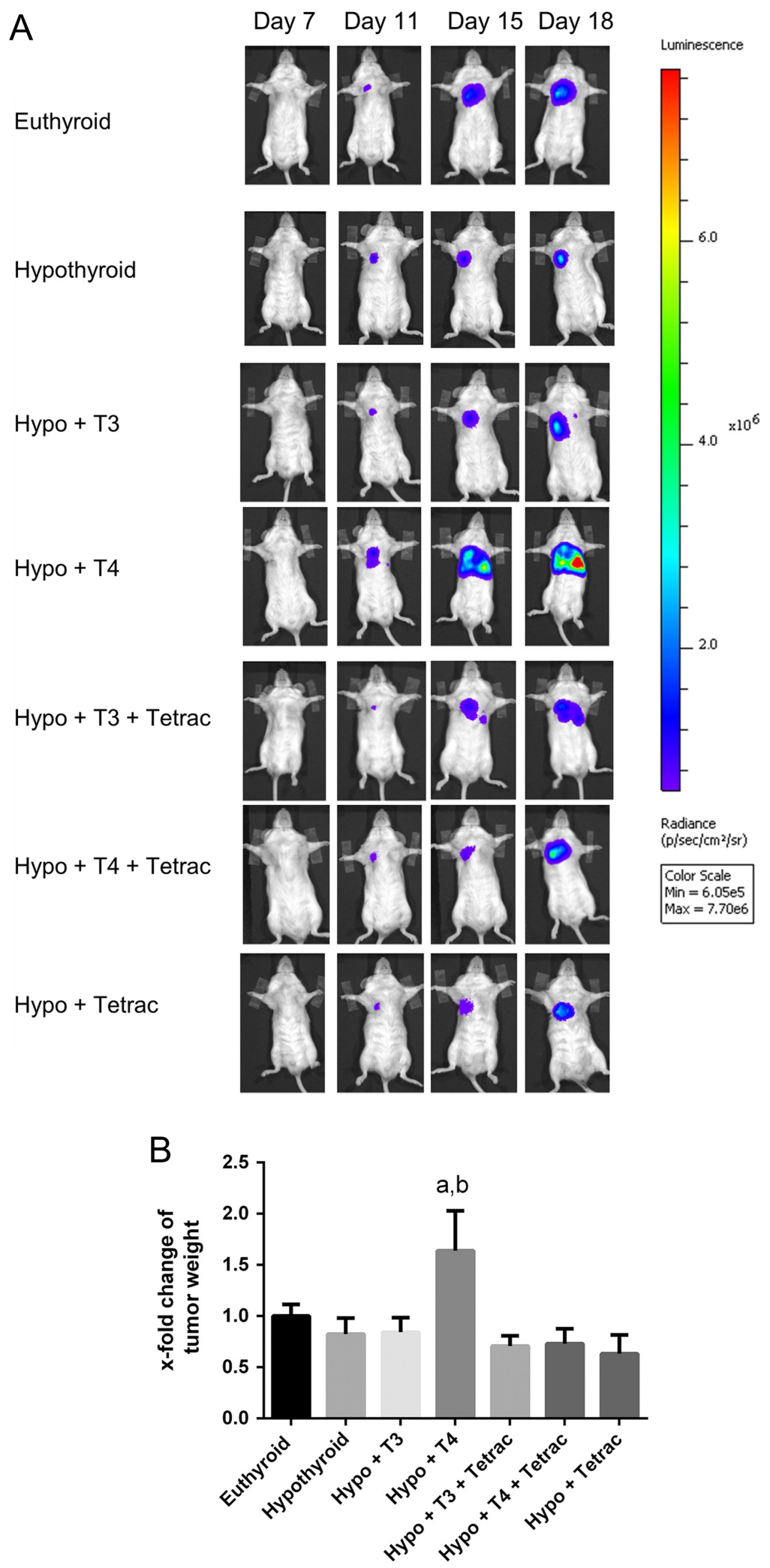

Figure 1

$\mathrm{T}_{4}$ treatment promotes tumor growth. (A) Exemplary illustration of bioluminescence intensity in one mouse per treatment group over time. (B) Tumor weight relative to euthyroid mice. $a=P<0.0001$ for $\mathrm{T}_{4}$-treated mice vs hypothyroid, $T_{3}$, Tetrac and $T_{3}+$ Tetrac-treated mice; $\mathrm{b}=P<0.01$ for $\mathrm{T}_{4}$ treated mice vs euthyroid mice, $n=6$. Mice were euthanized when predefined criteria were reached. 


\section{Immunohistochemistry}

All tissue sections were deparaffinized and rehydrated through graded alcohol baths $(70 \%-96 \%-100 \%$ ethanol, Sigma Aldrich). Following pretreatment in EDTA buffer (pH 9.0) at $95^{\circ} \mathrm{C}$ for $20 \mathrm{~min}$, the primary anti-CD31 antibody (D8V9E, Cell Signaling) was incubated for $30 \mathrm{~min}$ at room temperature. Immunoreactivity was detected with a classical polymer system (HRP) (Zytomed, Berlin, Germany). Cell nuclei were stained with haematoxylin (1:8; Roth, Karlsruhe, Germany) for 5 min (Dako Autostainer, Dako) and analyzed on an Olympus BX51 Upright microscope with Cell Sens Dimension software.

\section{Serum measurements}

TSH concentration was measured as previously described (Pohlenz et al. 1999). Serum total $\mathrm{T}_{4}\left(\mathrm{TT}_{4}\right)$ and free $\mathrm{T}_{3}\left(\mathrm{FT}_{3}\right)$ concentrations were measured using commercial ELISA kits according to the manufacturer's instructions (DRG Instruments $\mathrm{GmbH}$, Marburg, Germany; $\mathrm{FT}_{3}$ : EIA-2385; $\mathrm{TT}_{4}$ : EIA-1781) with a detection limit of $0.5 \mu \mathrm{g} / \mathrm{dL}$ for $\mathrm{TT}_{4}$ and $0.05 \mathrm{pg} / \mathrm{mL}$ for $\mathrm{FT}_{3}$.

\section{Statistical analysis}

Data were analyzed with one-way ANOVA (GraphPad Prism 6, GraphPad Software).

\section{Results}

\section{Induction of hypothyroidism}

Mice were rendered hypothyroid and treated with either $\mathrm{T}_{4}, \mathrm{~T}_{3}$, Tetrac or a combination of $\mathrm{TH}$ and Tetrac (Supplementary Fig. 2). Modulation of thyroid state was confirmed by body weight measurements and measurement of serum concentration of $\mathrm{TH}$ in final serum. Hypothyroidism led to a body weight plateau in hypothyroid mice, whereas euthyroid mice gained weight (Supplementary Fig. 3) (Engels et al. 2016). Induction of hypothyroidism was successful with significantly reduced TH concentration and elevated TSH (TSH $>8000$ vs $51 \mathrm{mU} / \mathrm{L} ; \mathrm{FT}_{3} 1.4$ vs $2.6 \mathrm{pg} / \mathrm{mL}$ and $\mathrm{TT}_{4} 0.34$ vs $2.7 \mu \mathrm{g} / \mathrm{dL}$ ). Treatment of hypothyroid mice with $\mathrm{T}_{3}$ or $\mathrm{T}_{4}$ resulted in increased $\mathrm{FT}_{3}$ and increased $\mathrm{TT}_{4}$ concentration, respectively (Supplementary Fig. 4). The ELISA could not distinguish between $\mathrm{T}_{4}$ and its derivative Tetrac and these groups are not displayed.

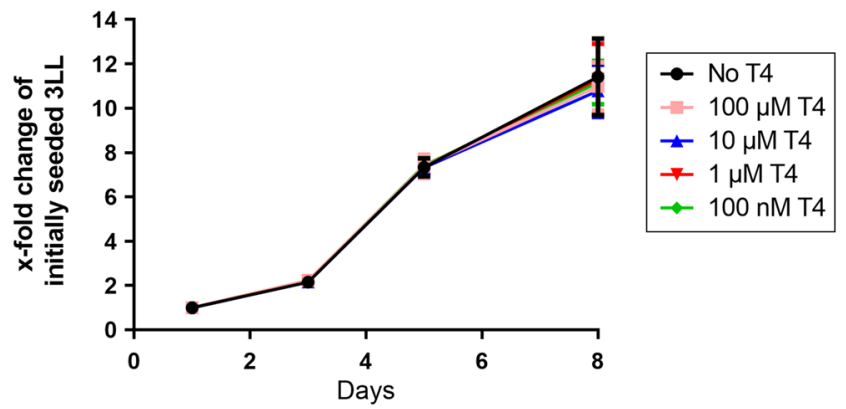

Figure 2

$\mathrm{T}_{4}$ does not stimulate Lewis lung carcinoma cell proliferation in vitro. Lewis lung cancer cells were grown in thyroid hormone-depleted medium or in the presence of $0.1,1,10$ and $100 \mu \mathrm{M} \mathrm{T}_{4}$. None of the $\mathrm{T}_{4}$ doses increased cell proliferation.

\section{$\mathbf{T}_{4}$ treatment promotes tumor growth, which is abolished by Tetrac}

Tumor progression was determined by serial in vivo bioluminescence imaging of light emission from the luciferaseexpressing 3LLcells. Compared to euthyroidmice, hypothyroidism in mice led to reduced bioluminescence signal intensity (Fig. 1A and Supplementary Table 1). Signal intensity was increased in $\mathrm{T}_{4}$-treated mice, but not in $\mathrm{T}_{3}$-treated mice (Fig. 1A). Bioluminescence doubling time as a measure of tumor progress was shortest in $\mathrm{T}_{4}$ treated mice (Supplementary Table 1). This effect was abrogated by Tetrac. Similarly, lung tumor weight was significantly increased only in $\mathrm{T}_{4}$-treated mice, but not in $\mathrm{T}_{3}$-treated mice (Fig. 1B, Supplementary Table 2). This $\mathrm{T}_{4}$-mediated effect was abolished by Tetrac treatment, resulting in diminished bioluminescence signal intensity and smaller tumor weight of $\mathrm{T}_{4} /$ Tetrac-treated animals compared to $\mathrm{T}_{4}$-treated mice. These data demonstrate

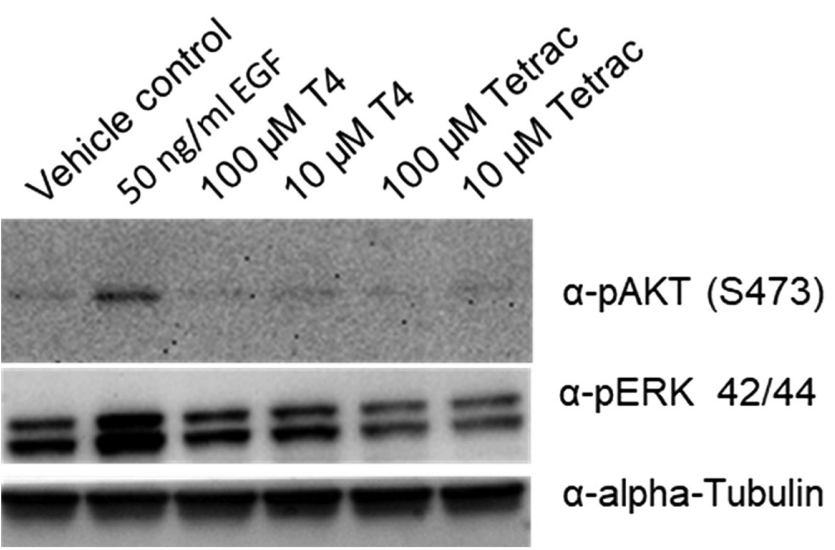

Figure 3

Signaling pathway activation. $3 \mathrm{LL}$ cells were treated with $\mathrm{T}_{4}$ or Tetrac.

Compared to vehicle control, $\mathrm{T}_{4}$ did not increase Akt or Erk phosphorylation. 

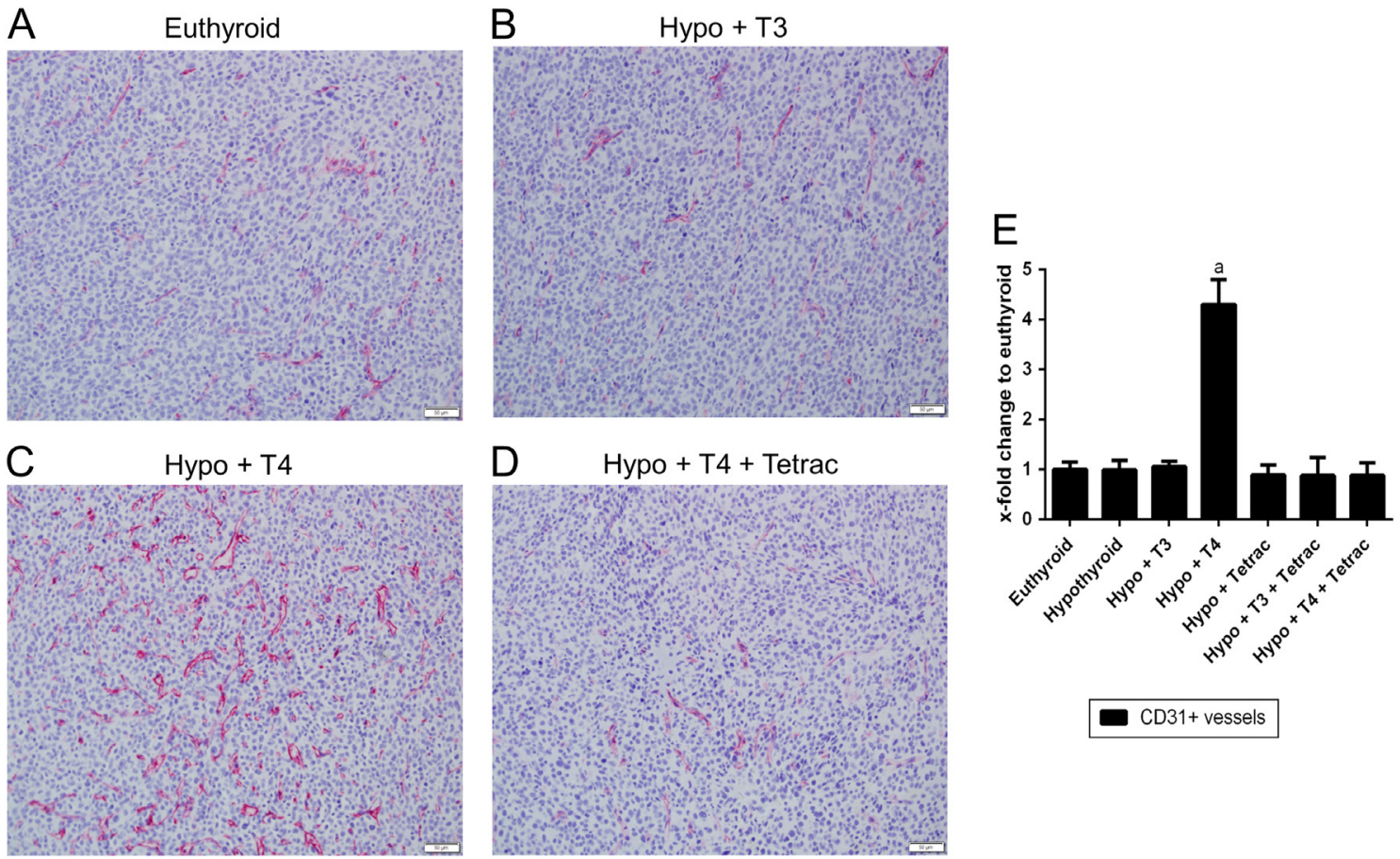

\section{Figure 4}

Increased CD31+ staining after $\mathrm{T}_{4}$ treatment. Immunohistochemistry staining of CD31+ from formalin-fixed paraffin-embedded tumor of (A) euthyroid mice, (B) $T_{3}$-treated mice, (C) $T_{4}$-treated mice and (D) $T_{4}+$ Tetrac-treated mice. (E) $T_{4}$-treated mice showed a significant increase of CD31+ vessels in thyroxine-treated mice compared to all other groups indicating neoangiogenesis. This effect was abolished in the presence of Tetrac. Bars represent $50 \mu \mathrm{M} ; \mathrm{a}=P<0.0001$ for $\mathrm{T}_{4}$-treated mice vs each other treatment group.

that $\mathrm{T}_{4}$ and not $\mathrm{T}_{3}$ promotes tumor growth. Overall survival, however, was not different between the treatment groups (Supplementary Fig. 5).

\section{$\mathrm{T}_{4}$ does not increase $3 \mathrm{LL}$ cell proliferation or signaling pathway activation}

To determine if $\mathrm{T}_{4}$ exerts a direct effect on proliferation of Lewis lung cells, we grew 3LL cells in $\mathrm{T}_{4}$-depleted medium and added $\mathrm{T}_{4}$ in doses from 0.1 to $100 \mu \mathrm{M}$. The cells showed the sigmoid proliferation curve. There was no difference in proliferation rate with any of the $\mathrm{T}_{4}$ doses (Fig. 2), indicating that $\mathrm{T}_{4}$ does not directly stimulate 3LL cell growth. Furthermore, neither Akt nor Erk phosphorylation was increased by $\mathrm{T}_{4}$ treatment (Fig. 3). Together, these results suggest that the tumor-promoting effect may not originate in the 3LL cells themselves but may rather be due to increased neoangiogenesis.

\section{$\mathbf{T}_{4}$ promotes tumor neoangiogenesis}

As it was shown previously that $\mathrm{T}_{4}$ increases neoangiogenesis in chick chorioallantoic membrane assays, we determined the extent of neoangiogenesis in the tumors by staining for platelet endothelial cell adhesion molecule,
CD31 (Mousa et al. 2008). We observed significantly increased vascularization in the tumors of $\mathrm{T}_{4}$-treated mice, which again was abrogated by co-treatment with Tetrac (Fig. 4A, B, C, D and E). $\mathrm{T}_{3}$ treatment alone had no effect. Of note, Tetrac alone did not reduce vascularization compared to tumors from untreated mice.

\section{Thyroid hormone does not influence AlphaV or Beta3 expression}

Next, we tested gene induction by TH in 3LL cells. AlphaV and Beta 3 mRNA expression was not changed by $\mathrm{T}_{3}$ or $\mathrm{T}_{4}$ (Fig. 5A and B), neither with short (6h) nor long (24h) term treatment. However, expression of known TH-responsive genes Klf9 and Vegf was induced in $3 \mathrm{LL}$ cells by $\mathrm{T}_{3}$ and $\mathrm{T}_{4}$ (Fig. 5C and D). Induction of both genes was not affected by pretreatment with the $\alpha_{v} \beta_{3}$ inhibitor Tetrac, which suggests that their induction does not depend on $\alpha_{\mathrm{v}} \beta_{3}$ but is rather mediated by the canonical TRs.

\section{Treatment with thyroid hormone does not alter the composition of infiltrating immune cells}

To investigate if the composition of infiltrating immune cells, which also express $\alpha_{v} \beta_{3}$, is altered in tumors we 
characterized the tumor infiltrate by flow cytometry. No significant differences were found between tumors from euthyroid mice or any of the treatment groups for the composition of infiltrating T-regs (CD4+, Foxp3+), cytotoxic T-cells (CD3+, CD8+), tumor-associated macrophages (F4/80+, Gr-1+), macrophages (F4/80+), natural killer cells (NK 1.1+), T-helper cells (CD3+, CD4+) or dendritic cells (CD11c+) (Table 1).

\section{Discussion}

TH can bind to the plasma membrane receptor integrin $\alpha_{v} \beta_{3}$, which mediates signaling across the membrane (Bergh et al. 2005). $\alpha_{v} \beta_{3}$ is expressed in invasive tumors, endothelial cells and inflammatory sites, especially in

activated macrophages, monocytes, neutrophils, natural killer cells and naive T lymphocytes (Piali et al. 1995, Eliceiri \& Cheresh 1998, Wilder 2002). Here, we show that growth of orthotopically implanted Lewis lung cell carcinoma was promoted by $\mathrm{T}_{4}$.

Importantly, it was only $\mathrm{T}_{4}$ and not $\mathrm{T}_{3}$ treatment that showed a growth-stimulating effect on the 3LL tumors. This is supported by the fact that, due to conversion, the $T_{3}$ concentration was similar in $T_{4}$ and $\mathrm{T}_{3}$-treated mice and, thus, $\mathrm{T}_{3}$ cannot be responsible for the observed difference in tumor growth. The tumorpromoting effect of $\mathrm{T}_{4}$ on 3LL cells implanted in murine lungs was abrogated by co-treatment with the $\alpha_{v} \beta_{3}$ inhibitor Tetrac, which demonstrates that $\alpha_{v} \beta_{3}$ mediates this effect and not the nuclear TRs. This effect could either be mediated by a direct effect of $\mathrm{T}_{4}$ on 3LL cells,
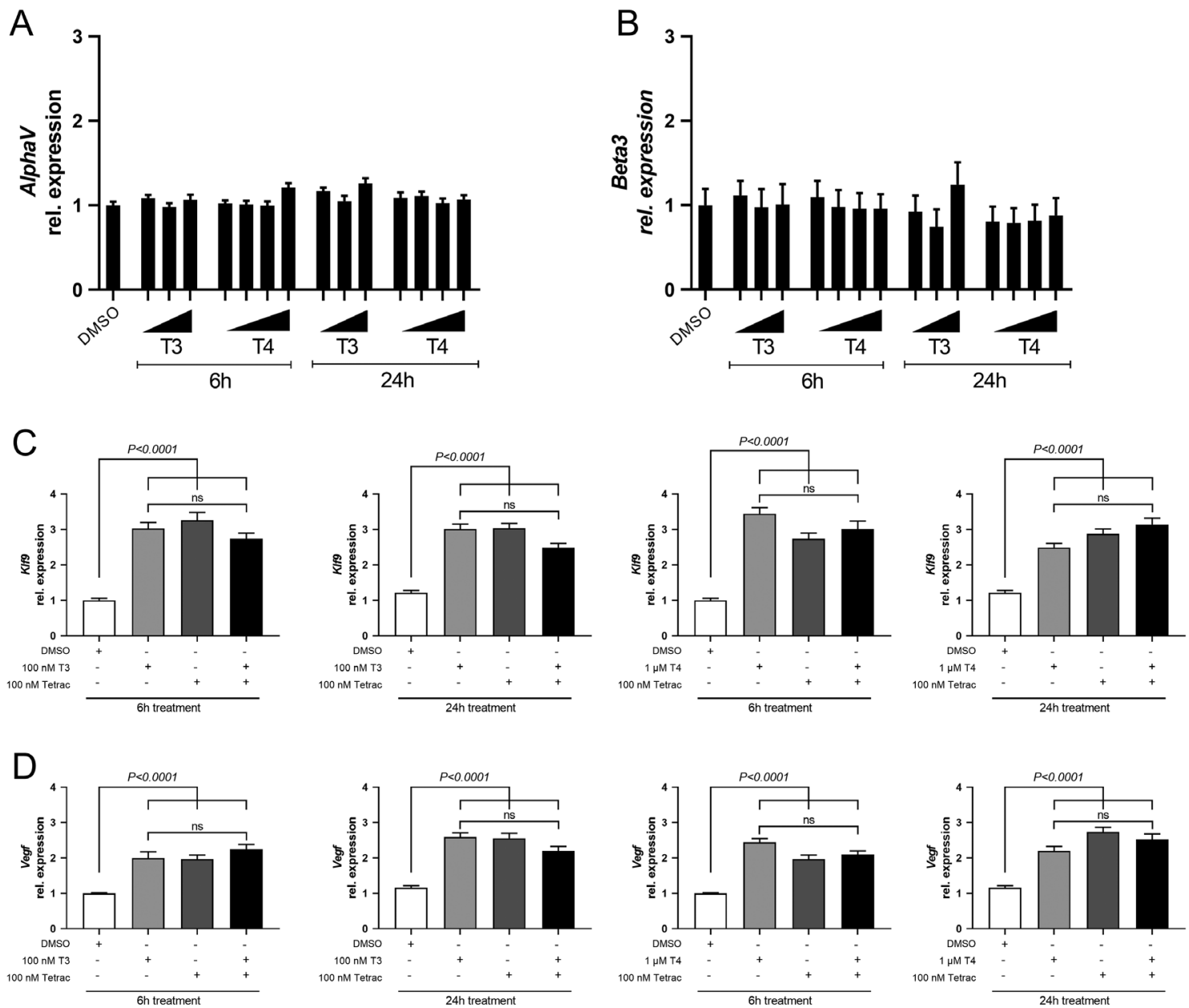

Figure 5

Expression of AlphaV (A) and Beta3 (B) in LLC determined after incubation with increasing doses of $\mathrm{T}_{3}(1,10$ and $100 \mathrm{nM})$ and $\mathrm{T}_{4}(1,10,100 \mathrm{nM}$ and $1 \mu \mathrm{M})$ for $6 \mathrm{~h}$ and $24 \mathrm{~h}$ (mean \pm S.E.M.). An increased expression of thyroid hormone responsive gene KIf9 (Krüppel-like factor 9) (C) and Vegf (vascular endothelial growth factor) (D) was detected after treatment with TH ( $\mathrm{T}_{3}, 100 \mathrm{nM}$ and $\left.\mathrm{T}_{4}, 1 \mu \mathrm{M}\right)$ or Tetrac $(100 \mathrm{nM})$ for $6 \mathrm{~h}$ and $24 \mathrm{~h}$ (mean \pm s.E.M.; one-way ANOVA with Tukey's post hoc test; ns = not significant). 


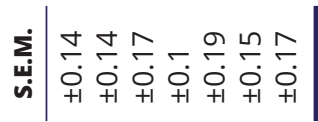

盇|

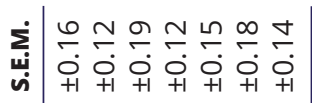

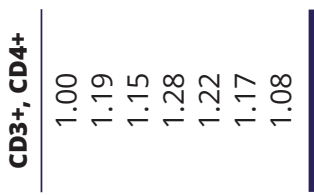

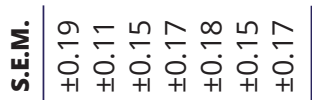

넘

妾

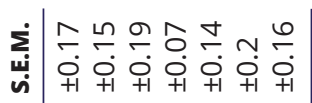

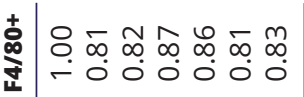

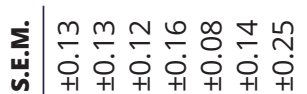

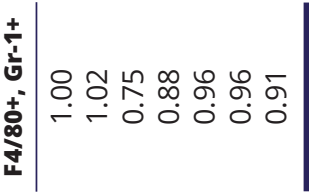

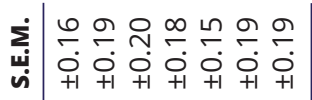

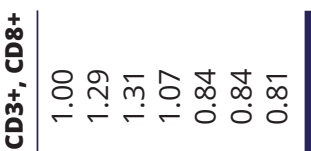

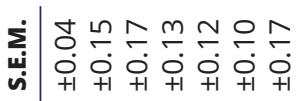

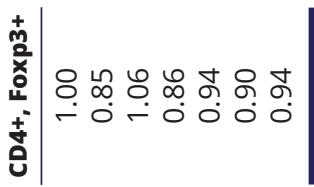

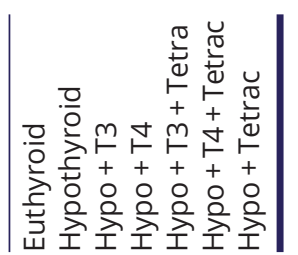

https://erc.bioscientifica.com

https://doi.org/10.1530/ERC-18-0353
(C) 2019 Society for Endocrinology Published by Bioscientifica Ltd. Printed in Great Britain increasing their proliferation, or by an indirect effect, for example, increased neovascularization of the tumors, or a combination of both. However, treatment of 3LL with $\mathrm{T}_{4}$ did not increase cell proliferation or signaling pathway activation. Tumors depend on an increased blood supply for rapid growth and $\alpha_{v} \beta_{3}$ acts proangiogenically. $\alpha_{v} \beta_{3}$ is expressed on endothelial cells and interacts with proangiogenic agents like FGF-2 (Sahni \& Francis 2004) and VEGFR2 (Masson-Gadais et al. 2003). Indeed, we found a significant increase of new vessels in $\mathrm{T}_{4}$-treated mice, which was completely abrogated by pretreatment with Tetrac. Together, these results suggest that $T_{4} / \alpha_{v} \beta_{3}$ stimulate tumor growth via increased neovascularization and not by direct 3LL cell stimulation.

Another set of $\mathrm{T}_{4}$ target cells within the tumors might be infiltrating immune cells that also express $\alpha_{v} \beta_{3}$ such as macrophages, natural killer cells and $\mathrm{T}$ lymphocytes. However, we did not detect any treatment-dependent changes in the immune cell profile.

Our findings correspond to clinical observations. Patients with NSCLC treated with the PD-1 blockers nivolumab and pembrolizumab frequently experience thyroid dysfunction, predominantly hypothyroidism which may be preceded by a short episode of hyperthyroidism due to destructive thyroiditis. According to two recent reports, progression-free and overall survival was significantly longer in hypothyroid patients with NSCLC and PD-1 blockade compared to euthyroid patients (Kim et al. 2017, Osorio et al. 2017). While it cannot be ruled out that hypothyroidism is only a surrogate marker of antitumor treatment efficacy due to higher drug concentrations or different susceptibility of the immune system in a subset of patients, our results suggest that thyroid hormone itself can indeed influence NSCLC progression by enhancing neovascularization via $\alpha_{v} \beta_{3}$.

Because $\mathrm{T}_{4}$ effects similar to those observed in this NSCLC mouse model have been previously reported in non-orthotopic approaches with 3LL, mammary adenocarcinoma (C3HBA) and fibrosarcoma (T241) cells (Shoemaker et al. 1976, Kumar et al. 1979, Kinoshita et al. 1991), promotion of tumor growth by $\mathrm{T}_{4}$ appears to be a more general phenomenon with implications for cancer patients. Hypothyroidism may develop during tyrosine kinase inhibitor treatment (Illouz et al. 2014, Schweizer et al. 2014) or due to autoimmune thyroiditis as a frequent side effect of checkpoint inhibitor treatment in advanced malignancies including lung cancer (Illouz et al. 2014). In these situations, substitution with thyroxine is considered. But there is reasonable concern that 
substituting these cancer patients with $\mathrm{T}_{4}$ could be harmful. Our results support the idea that in cancer patients, thyroxine may have more consequences than only normalizing TSH, and it seems necessary to determine which cancer entities are sensitive to TH. Future cancer treatment studies, especially with substances that can induce hypothyroidism, should be designed in a way that allows for an analysis of thyroid function status and its contribution on treatment outcome.

\section{Supplementary data}

This is linked to the online version of the paper at https://doi.org/10.1530/ ERC-18-0353.

\section{Declaration of interest}

The authors declare that there is no conflict of interest that could be perceived as prejudicing the impartiality of the research reported.

\section{Funding}

This work was funded by Deutsche Forschungsgemeinschaft (grants MO1018/2-1 to LCM and FU356/8-1 to DF) and the IFORES program, Faculty of Medicine, University of Duisburg-Essen.

\section{Author contribution statement}

SL and LCM designed the studies; SL, SC and GSH conducted experiments; SL, SC, ST, GSH, KWS, DF, LCM analyzed data; SL, SC and LCM wrote, and all authors contributed to the manuscript.

\section{Acknowledgements}

The authors are grateful to XiaoHui Liao and Dr. Samuel Refetoff, Department of Medicine, The University of Chicago, Chicago, USA, for measurement of thyroid function tests.

\section{References}

Bergh JJ, Lin HY, Lansing L, Mohamed SN, Davis FB, Mousa S \& Davis PJ 2005 Integrin alphaVbeta3 contains a cell surface receptor site for thyroid hormone that is linked to activation of mitogen-activated protein kinase and induction of angiogenesis. Endocrinology 146 2864-2871. (https://doi.org/10.1210/en.2005-0102)

Cao X, Kambe F, Yamauchi M \& Seo H 2009 Thyroid-hormonedependent activation of the phosphoinositide 3-kinase/Akt cascade requires Src and enhances neuronal survival. Biochemical Journal $\mathbf{4 2 4}$ 201-209. (https://doi.org/10.1042/BJ20090643)

Christoph S, Deryckere D, Schlegel J, Frazer JK, Batchelor LA, Trakhimets AY, Sather S, Hunter DM, Cummings CT, Liu J et al. 2013 UNC569, a novel small-molecule mer inhibitor with efficacy against acute lymphoblastic leukemia in vitro and in vivo. Molecular Cancer Therapeutics 12 2367-2377. (https://doi.org/10.1158/1535-7163.MCT13-0040)

Davis PJ, Davis FB, Mousa SA, Luidens MK \& Lin HY 2011 Membrane receptor for thyroid hormone: physiologic and pharmacologic implications. Annual Review of Pharmacology \& Toxicology 51 99-115. (https://doi.org/10.1146/annurev-pharmtox-010510-100512)

Davis PJ, Lin HY, Sudha T, Yalcin M, Tang HY, Hercbergs A, Leith JT, Luidens MK, Ashur-Fabian O, Incerpi S et al. 2014 Nanotetrac targets integrin alphavbeta3 on tumor cells to disorder cell defense pathways and block angiogenesis. OncoTargets and Therapy 7 1619-1624. (https://doi.org/10.2147/OTT.S67393)

Eliceiri BP \& Cheresh DA 1998 The role of alphav integrins during angiogenesis. Molecular Medicine 4 741-750. (https://doi.org/10.1007/ BF03401768)

Engels K, Rakov H, Zwanziger D, Hones GS, Rehders M, Brix K, Kohrle J, Moller LC \& Fuhrer D 2016 Efficacy of protocols for induction of chronic hyperthyroidism in male and female mice. Endocrine $\mathbf{5 4}$ 47-54. (https://doi.org/10.1007/s12020-016-1020-8)

Flamant F, Cheng SY, Hollenberg AN, Moeller LC, Samarut J, Wondisford FE, Yen PM \& Refetoff S 2017 Thyroid hormone signaling pathways. Time for a more precise nomenclature. Endocrinology 158 2052-2057. (https://doi.org/10.1210/en.201700250)

Freindorf M, Furlani TR, Kong J, Cody V, Davis FB \& Davis PJ 2012 Combined $\mathrm{QM} / \mathrm{MM}$ study of thyroid and steroid hormone analogue interactions with alphavbeta3 integrin. Journal of Biomedicine \& Biotechnology 2012 959057. (https://doi.org/10.1155/2012/959057)

Hall LC, Salazar EP, Kane SR \& Liu N 2008 Effects of thyroid hormones on human breast cancer cell proliferation. Journal of Steroid Biochemistry \& Molecular Biology 109 57-66. (https://doi. org/10.1016/j.jsbmb.2007.12.008)

Hönes GS, Rakov H, Logan J, Liao XH, Werbenko E, Pollard AS, Præstholm SM, Siersbæk MS, Rijntjes E, Gassen J et al. 2017 Noncanonical thyroid hormone signaling mediates cardiometabolic effects in vivo. PNAS 114 E11323-E11332. (https://doi.org/10.1073/ pnas.1706801115)

Illouz F, Braun D, Briet C, Schweizer U \& Rodien P 2014 Endocrine sideeffects of anti-cancer drugs: thyroid effects of tyrosine kinase inhibitors. European Journal of Endocrinology 171 R91-R99. (https:// doi.org/10.1530/EJE-14-0198)

Kim HI, Kim M, Lee SH, Park SY, Kim YN, Kim H, Jeon MJ, Kim TY, Kim SW, Kim WB et al. 2017 Development of thyroid dysfunction is associated with clinical response to PD-1 blockade treatment in patients with advanced non-small cell lung cancer. Oncoimmunology 7 e1375642. (https://doi.org/10.1080/2162402X.2017.1375642)

Kinoshita S, Sone S, Yamashita T, Tsubura E \& Ogura T 1991 Effects of experimental hyper- and hypothyroidism on natural defense activities against Lewis lung carcinoma and its spontaneous pulmonary metastases in C57BL/6 mice. Tokushima Journal of Experimental Medicine 38 25-35.

Kumar MS, Chiang T \& Deodhar SD 1979 Enhancing effect of thyroxine on tumor growth and metastases in syngeneic mouse tumor systems. Cancer Research 39 3515-3518.

Lin HY, Tang HY, Keating T, Wu YH, Shih A, Hammond D, Sun M, Hercbergs A, Davis FB \& Davis PJ 2008 Resveratrol is pro-apoptotic and thyroid hormone is anti-apoptotic in glioma cells: both actions are integrin and ERK mediated. Carcinogenesis 29 62-69. (https://doi. org/10.1093/carcin/bgm239)

Lin HY, Sun M, Tang HY, Lin C, Luidens MK, Mousa SA, Incerpi S, Drusano GL, Davis FB \& Davis PJ 2009 L-Thyroxine vs. 3,5,3'-triiodo-L-thyronine and cell proliferation: activation of mitogen-activated protein kinase and phosphatidylinositol 3-kinase. American Journal of Physiology. Cell Physiology 296 C980-C991. (https://doi.org/10.1152/ajpcell.00305.2008)

Masson-Gadais B, Houle F, Laferriere J \& Huot J 2003 Integrin alphavbeta3, requirement for VEGFR2-mediated activation of SAPK2/p38 and for Hsp90-dependent phosphorylation of focal adhesion kinase in endothelial cells activated by VEGF. Cell Stress \& Chaperones 8 37-52. (https://doi.org/10.1379/14661268(2003)8<37:IVRFVA >2.0.CO;2) 
Meng R, Tang HY, Westfall J, London D, Cao JH, Mousa SA, Luidens M, Hercbergs A, Davis FB, Davis PJ et al. 2011 Crosstalk between integrin alphavbeta3 and estrogen receptor-alpha is involved in thyroid hormone-induced proliferation in human lung carcinoma cells. PLoS One 6 e27547. (https://doi.org/10.1371/journal. pone.0027547)

Mousa SA, Bergh JJ, Dier E, Rebbaa A, O'Connor LJ, Yalcin M, Aljada A, Dyskin E, Davis FB, Lin HY et al. 2008 Tetraiodothyroacetic acid, a small molecule integrin ligand, blocks angiogenesis induced by vascular endothelial growth factor and basic fibroblast growth factor. Angiogenesis 11 183-190. (https://doi.org/10.1007/s10456007-9088-7)

Niu JX, Zhang WJ, Ye LY, Wu LQ, Zhu GJ, Yang ZH, Grau GE \& Lou JN 2007 The role of adhesion molecules, alpha $\mathrm{v}$ beta 3 , alpha $\mathrm{v}$ beta 5 and their ligands in the tumor cell and endothelial cell adhesion. European Journal of Cancer Prevention 16 517-527. (https://doi. org/10.1097/CEJ.0b013e3280145c00)

Osorio JC, Ni A, Chaft JE, Pollina R, Kasler MK, Stephens D, Rodriguez C, Cambridge L, Rizvi H, Wolchok JD et al. 2017 Antibody-mediated thyroid dysfunction during T-cell checkpoint blockade in patients with non-small-cell lung cancer. Annals of Oncology 28 583-589. (https://doi.org/10.1093/annonc/mdw640)

Pfaffl MW 2001 A new mathematical model for relative quantification in real-time RT-PCR. Nucleic Acids Research 29 e45. (https://doi. org/10.1093/nar/29.9.e45)

Piali L, Hammel P, Uherek C, Bachmann F, Gisler RH, Dunon D \& Imhof BA 1995 CD31/PECAM-1 is a ligand for alpha $v$ beta 3 integrin involved in adhesion of leukocytes to endothelium. Journal of Cell Biology 130 451-460. (https://doi.org/10.1083/jcb.130.2.451)
Poczobutt JM, Gijon M, Amin J, Hanson D, Li H, Walker D, WeiserEvans M, Lu X, Murphy RC, Nemenoff RA 2013 Eicosanoid profiling in an orthotopic model of lung cancer progression by mass spectrometry demonstrates selective production of leukotrienes by inflammatory cells of the microenvironment. PLoS One 8 e79633. (https://doi.org/10.1371/journal.pone.0079633)

Pohlenz J, Maqueem A, Cua K, Weiss RE, Van Sande J \& Refetoff S 1999 Improved radioimmunoassay for measurement of mouse thyrotropin in serum: strain differences in thyrotropin concentration and thyrotroph sensitivity to thyroid hormone. Thyroid 9 1265-1271. (https://doi.org/10.1089/thy.1999.9.1265)

Sahni A \& Francis CW 2004 Stimulation of endothelial cell proliferation by FGF-2 in the presence of fibrinogen requires alphavbeta3. Blood 104 3635-3641. (https://doi.org/10.1182/blood-2004-04-1358)

Schweizer U, Johannes J, Bayer D \& Braun D 2014 Structure and function of thyroid hormone plasma membrane transporters. European Thyroid Journal 3 143-153. (https://doi. org $/ 10.1159 / 000367858)$

Shoemaker JP, Bradley RL \& Hoffman RV 1976 Increased survival and inhibition of mammary tumors in hypothyroid mice. Journal of Surgical Research 21 151-154. (https://doi.org/10.1016/0022-4804(76)90151-7)

Tsui KH, Hsieh WC, Lin MH, Chang PL \& Juang HH 2008 Triiodothyronine modulates cell proliferation of human prostatic carcinoma cells by downregulation of the B-cell translocation gene 2. Prostate 68 610-619. (https://doi.org/10.1002/pros.20725)

Wilder RL 2002 Integrin alpha V beta 3 as a target for treatment of rheumatoid arthritis and related rheumatic diseases. Annals of the Rheumatic Diseases 61 (Supplement 2) ii96-ii99. (https://doi. org/10.1136/ard.61.suppl_2.ii96)

Received in final form 28 February 2019

Accepted 20 March 2019

Accepted Preprint published online 20 March 2019 (c) 2019 Society for Endocrinology Published by Bioscientifica Ltd. Printed in Great Britain 